\title{
THE EFFECTIVENESS OF NUTRITION EDUCATION THROUGH SOCIO-DRAMATIC METHOD TO VEGETABLE \& FRUIT KNOWLEDGE AND CONSUMPTION IN 5-6 YEARS OLD CHILDREN
}

\author{
Luluk Hidayatul Maghfiroh ${ }^{1}$, A Fahmy Arif Tsani ${ }^{1,2}$, Fillah Fithra Dieny ${ }^{1,2^{*}}$, Etisa Adi Murbawani ${ }^{1}$ Rachma \\ Purwanti ${ }^{1}$ \\ ${ }^{1}$ Department of Nutrition, Faculty of Medicine, Universitas Diponegoro, Semarang, Indonesia \\ ${ }^{2}$ Center of Nutrition Research (CENURE) Faculty of Medicine Universitas Diponegoro, Semarang, Indonesia \\ *E-mail: fillahdieny@gmail.com
}

\begin{abstract}
Low consumption of vegetable and fruit in children was still commonly found. Appropriate and effective nutrition education methods are needed to increase knowledge and consumption of vegetable and fruit in children. This study aimed to know the effectiveness of nutrition education through socio-dramatic method of vegetable and fruit knowledge and consumption in children 5-6 years old. This study was a quasi-experiment with pre-test and post-test control group design. Research subjects were 36 Taman Putra Kindergarten children who were divided into treatment group who were given nutrition education with socio-dramatic method, and control group who were given nothing. The improvement of nutrition knowledge was assessed by pre-test and post-test with pictured form, while vegetable and fruit consumption were assessed by 3 Days Food Record instrument. A total of 15 subjects had low fruit vegetable knowledge, and more than $50 \%$ of subjects had less fiber intake, types of vegetable consumption $<7$ types, the amount of vegetable intake $<250$ grams, and fruit $<150$ grams. The provision of nutritional education through sociodrama method was effective in increasing knowledge of fruit vegetables in pre-school children $(\mathrm{p}<0.001)$, as seen from the increase in average knowledge of treatment group compared to control group. But unfortunately, nutrition education through sociodrama method has not been able to significantly increase fruit vegetable consumption in terms of both quantity and type ( $\mathrm{p}>$ $0.05)$.
\end{abstract}

Keywords: nutrition education, nutrition knowledge, socio-dramatic method, vegetable and fruit consumption in children

\section{INTRODUCTION}

The Ministry of Health of the Republic of Indonesia in 2009 divides children's age into under-five children ( $0-5$ years old) and child (5-11 years old). Childhood is a period of optimal growth and development in a person's social, cognitive and emotional (Lucas \& Feucht, 2008). Children have several developmental characteristics, one of which is social development. The typical development of preschool children is to like imitative, imaginative and dramatic games (Wong et al, 2018). Cognitive development in the preschool children will continue to develop language skills that tend to be egocentric.

Toddlers and preschoolers are prone to experiencing nutritional problems which will affect the child's growth and development. Malnutrition in children is associated with poor cognitive, mental and academic performance in school (Martins et al., 2011). Globally, about 45\% of under-five mortality is caused by malnutrition. One aspect that affects individual health is eating behavior (Muckenhuber, et al, 2014). Knowledge of what to eat will certainly influence individual eating behavior. Nutritional knowledge is defined as an individual cognitive process related to information about food and nutrition and is related to the selection of healthy foods and the success of preventing a disease, so that knowledge is needed so that individuals can change their lifestyle in order to improve the health status (Barbosa et al., 2016).

The vegetable and fruit consumption survey conducted in Indonesia shows that the lowest vegetable consumption rate is in the under five children (Hermina \& Prihatini, 2016). There are several factors that affect fruit vegetable intake including age, gender, diet quality, knowledge and food preferences (Bestari \& Pramono, 2014). 
Physical environmental factors include the availability and accessibility of vegetables \& fruit as well as social environmental factors such as socioeconomic status and support from parents, teachers and schools (Graziose \& Ang, 2018). The school environment is a suitable place for health promotion interventions in school-age children (Nekitsing et al., 2018). Nutrition education in schools has a great opportunity to increase knowledge and become the basis for changing children's behavior (Desi et al., 2018). School age children tend to be active, play a lot and also ask questions. So that the chosen educational method is a method that allows children to participate and be actively involved in activities (Khairunnisya et al., 2017).

Sociodrama is a role-playing learning method to solve problems related to social phenomena. This game combines 2 elements, namely imitative and imaginative. Imitative, which is when children imitate someone's actions or words. Whereas imaginative when children use their imagination to create what is imitated (Smilansky, 1968). By applying the sociodrama method in nutrition education, children can easily absorb the messages or material being taught. This method encourages children to explore together, ask questions to each other, find answers and reflect on their everyday life (Mclennan, 2008).

The sociodrama method used in this study is to play roles collectively, including the introduction of vegetables through playing roles as buyers and sellers as well as introduction of fruit by means of the subjects being small chefs who process fruits into fruit salads. Research on the effect of nutrition education on vegetables and fruit using the sociodrama method has never been conducted before in Indonesia, so researchers are interested in applying it and analyzing its effect on changes in knowledge and behavior of fruit vegetable consumption in pre-school children.

\section{METHODS}

The study was used pre-posttest control group quasi experimental design. The study was divided into a control group and a treatment group which given a test before and after the intervention. The population was all students of Taman Putra
Kindergarten, Semarang. The subjects as the unit of analysis were kindergarten children and the respondents were the subject's mother. The sample size used in this study was 18 for each group. The inclusion criteria were subjects aged 5-6 years and parents willing to take part in the study. The exclusion criteria were that the subjects moved or dropped out of school during the study and students did not participate in any of the research series. Each respondent or selected subject's parents provided informed consent as a sign that the subjects agreed to participate in the study. This study has received the approval of the Research Ethics Committee of the Faculty of Medicine, Diponegoro University / Dr Kariadi Semarang Hospital No. 350 / EC / KEPK / FK-UNDIP / VII $/ 2019$.

The level of knowledge and consumption of fruit vegetables was the dependent variable. While the independent variable was the provision of fruit vegetable nutrition education using the sociodrama method which was carried out for 1 week.

Anthropometric measurements were carried out to determine the nutritional status of children. Body weight measured using the Gea Medical brand digital weight scale with an accuracy of 0.1 $\mathrm{kg}$. Meanwhile, height was measured using the Gea Medical brand microtoise with an accuracy of $0.1 \mathrm{~cm}$. The measurement results are then grouped based on the z-score of BMI / Age, i.e., very thin category if $<-3 \mathrm{SD}$, thin $-3 \mathrm{SD}$ to $<-2$ $\mathrm{SD}$, normal $-2 \mathrm{SD}$ to $1 \mathrm{SD}$, fat $>1 \mathrm{SD}$ to $2 \mathrm{SD}$, and obesity $>2$ SD (Ministry of Health, 2011). Changes in vegetable and fruit consumption were seen using the 3 Days Food Record instrument which was taken before the intervention and after the intervention which was then analyzed using the Nutrisurvey software. The 3 Days Food Record is filled in by the subject's parents who act as research respondents. The amount of fiber is categorized into mild deficit, moderate deficit, severe deficit, normal and more. Information about consumption habits and availability of fruit vegetables was obtained by using a questionnaire on habits and availability of fruit vegetables that was developed by the researcher and filled in by the students' parents. The number of vegetables and fruit consumption was categorized according to WHO recommendations; moderate vegetable 
consumption ( $\geq 250 \mathrm{~g})$ and less $(<250 \mathrm{~g})$, while the category of fruit is sufficient $(\geq 150 \mathrm{~g})$ and less $(<150 \mathrm{~g})$. Types of vegetables and fruit were categorized based on variations for 7 days; $<7$ types and $\geq 7$ types. Changes in knowledge were seen using the pre-test and post-test in the form of questions about vegetables and fruit totaling 15 questions. The pre-test and post-test question models are adjusted to the abilities of children aged 5-6 years with 3 question models, those are choosing images, matching pictures with writing, and matching pictures with pictures (Kemendikbud RI, 2014, 2015). The nutritional knowledge scores were categorized into good knowledge (76$100 \%$ ), sufficient knowledge (56-75\%), and low knowledge $(<55 \%)$ (Wawan, 2011).

The intervention in the treatment group was given sociodrama games about vegetables and fruit, while the control group was not given any intervention. If nutrition education in children is usually carried out by the lecture or storytelling method, in this sociodrama method, the children are invited to be actively involved in playing roles in which the education or information needed is tucked in. In this study, before the sociodrama game, the children were introduced to vegetables and fruit and their benefits using educational card instruments. Educational cards containing pictures of vegetables and fruits and their benefits. The sociodrama game was held for 1 day and consisted of 2 sessions. Each session lasts 1 hour. The first session was about vegetables, children were asked to play the roles of sellers and buyers of vegetables. The second session was about fruit, the children played the role of a chef and made fruit salads together.

The statistical test used in this study was the Paired T-Test and Wilcoxon test to analyze the effect of the intervention in each group, while the effect of the intervention on changes in the dependent variable between the treatment and control groups used the Mann Whitney U test and Independent T-Test. Data analysis was obtained using Statistical Package for the Social Sciences (SPSS) version 21.

\section{RESULTS AND DISCUSSION}

Based on the screening result, it was found that 48 children were divided into 2 classes. In the middle of the study, there were 12 children from both classes who dropped out because they did not follow the complete research course and there were problematic data. Then 18 children were taken from each group to become research subjects.

Table 1 shows the study subjects consisted of $44.4 \%$ boys and $55.6 \%$ girls in the control group and the treatment group. Respondents are parents or caregivers who know the subject's eating behavior every day. Most of the parents had a minimum college education and earned more than the Semarang minimum wage. Most of the subjects in the control group and $50 \%$ of the subjects in the treatment group had normal nutritional status. Before the intervention, $50 \%$ of subjects in the treatment group still have low nutrition knowledge (Table 2). Likewise, with the data on Likewise, with the data on vegetable and fruit consumption, $94.4 \%$ of the control group and $100 \%$ of the treatment group showed a severe deficit in the fiber intake. The types and amounts of fruit and vegetables consumed also do not meet the specified adequacy standards. Although there was no significant difference, there was an increase in the number of types of vegetables and fruit consumed. In the treatment

Table 1. Frequency Distribution of Subject Characteristics

\begin{tabular}{|c|c|c|c|c|}
\hline \multirow{2}{*}{ Variable } & \multicolumn{2}{|c|}{ Treatment } & \multicolumn{2}{|c|}{ Control } \\
\hline & $\mathbf{n}$ & $\%$ & $\mathbf{n}$ & $\%$ \\
\hline \multicolumn{5}{|l|}{ Gender } \\
\hline Boys & 8 & 44.4 & 8 & 44.4 \\
\hline Girls & 10 & 55.6 & 10 & 55.6 \\
\hline \multicolumn{5}{|l|}{ Father's occupation } \\
\hline High school & 2 & 11.1 & 1 & 5.6 \\
\hline College & 16 & 88.9 & 17 & 94.4 \\
\hline \multicolumn{5}{|l|}{ Mother's occupation } \\
\hline High school & 1 & 5.6 & 2 & 11.1 \\
\hline College & 17 & 94.4 & 16 & 88.9 \\
\hline \multicolumn{5}{|l|}{ Parents' income } \\
\hline$<$ Minimum wage* & 2 & 11.1 & 0 & 0.0 \\
\hline$\geq$ Minimum wage & 16 & 88.9 & 18 & 100 \\
\hline \multicolumn{5}{|c|}{ Nutritional status (BMI/Age) } \\
\hline Thin & 1 & 5.6 & 2 & 11.1 \\
\hline Normal & 14 & 77.8 & 9 & 50.0 \\
\hline Overweight & 0 & 0.0 & 4 & 22.2 \\
\hline Obese & 3 & 16.6 & 3 & 16.7 \\
\hline
\end{tabular}


Table 2. Characteristics of Subjects Before Intervention

\begin{tabular}{|c|c|c|c|c|}
\hline \multirow{2}{*}{ Variable } & \multicolumn{2}{|c|}{ Control } & \multicolumn{2}{|c|}{ Treatment } \\
\hline & $\mathbf{n}$ & $\%$ & $\mathbf{n}$ & $\%$ \\
\hline \multicolumn{5}{|l|}{ Nutrition knowledge } \\
\hline Low $(\leq 55 \%)$ & 6 & 33.0 & 9 & 50.0 \\
\hline Sufficient (56-75\%) & 10 & 55.6 & 7 & 38.9 \\
\hline Good (76-100\%) & 2 & 11.1 & 2 & 11.1 \\
\hline \multicolumn{5}{|l|}{ Fiber intake (g) } \\
\hline Severe deficit $(<70 \%)$ & 17 & 94.4 & 18 & 100 \\
\hline Moderate deficit (70-79\%) & 1 & 5.60 & 0 & 0.0 \\
\hline \multicolumn{5}{|l|}{ Type of vegetables* } \\
\hline$<7$ types & 17 & 94.4 & 18 & 100 \\
\hline$\geq 7$ types & 1 & 5.6 & 0 & 0.0 \\
\hline \multicolumn{5}{|l|}{ Type of fruits* } \\
\hline$<7$ types & 18 & 100 & 18 & 100 \\
\hline$\geq 7$ types & 0 & 0.0 & 0 & 0.0 \\
\hline \multicolumn{5}{|l|}{ Vegetable intake (g) } \\
\hline Less $(<250 \mathrm{~g})$ & 18 & 100 & 18 & 100 \\
\hline Moderate $(\geq 250 \mathrm{~g})$ & 0 & 0.0 & 0 & 0.0 \\
\hline \multicolumn{5}{|l|}{ Fruit intake (g) } \\
\hline Less $(<150 \mathrm{~g})$ & 16 & 88.9 & 15 & 83.3 \\
\hline Sufficient $(\geq 150 \mathrm{~g})$ & 2 & 11.1 & 3 & 16.7 \\
\hline
\end{tabular}

*Types of vegetables and types of fruit eaten per week

Table 3. Changes of nutrition knowledge and consumption of fruit $\&$ vegetables before and after the intervention in the control group

\begin{tabular}{lccc}
\hline \multirow{2}{*}{ Variable } & \multicolumn{2}{c}{ Mean \pm SD } & p \\
\cline { 2 - 3 } & $\begin{array}{c}\text { Before } \\
\text { intervention }\end{array}$ & $\begin{array}{c}\text { After } \\
\text { intervention }\end{array}$ & \\
\hline $\begin{array}{l}\text { Score of } \\
\text { nutrition } \\
\text { knowledge }\end{array}$ & $9.44 \pm 1.7$ & $10.28 \pm 1.4$ & $0.207^{\mathbf{a}}$ \\
$\begin{array}{l}\text { Fiber intake } \\
\text { g) }\end{array}$ & $5.62 \pm 3.3$ & $5.75 \pm 3.6$ & $0.647^{\mathbf{a}}$ \\
$\begin{array}{l}\text { Type of } \\
\text { vegetables/ }\end{array}$ & $3.72 \pm 1.6$ & $3.61 \pm 1.7$ & $0.782^{\mathbf{b}}$ \\
$\begin{array}{l}\text { week } \\
\begin{array}{l}\text { Types of } \\
\text { fiber/ week }\end{array}\end{array}$ & $2.11 \pm 1.6$ & $1.83 \pm 1.5$ & $0.296^{\mathbf{a}}$ \\
$\begin{array}{l}\text { Vegetable } \\
\text { intake (g) }\end{array}$ & $38.85 \pm 29.7$ & $43.40 \pm 25.7$ & $0.566^{\mathbf{b}}$ \\
$\begin{array}{l}\text { Fruit intake } \\
(\mathrm{g})\end{array}$ & $65.15 \pm 70.5$ & $90.62 \pm 77.6$ & $0.052^{\mathbf{b}}$ \\
\hline
\end{tabular}

${ }^{\mathrm{a}}$ Wilcoxon test ${ }^{\mathrm{b}}$ Paired T-Test

group, there was an increase of $44.4 \%$ of subjects who consumed $\geq 7$ types of vegetables per week after the intervention.
Table 3 shows the increase in knowledge before and after intervention in the control group but not significant ( $p>0.05$ ). Whereas Table 4 in the treatment group, only the knowledge variable showed a significant difference $(\mathrm{p}<0.05)$ before and after the intervention.

Most of the parents at least having a college education. These data indicate that the education level of the subjects' parents in both groups are the same. This means that the acceptance of information by parents is also relatively homogeneous. Parents' income was mostly higher than minimum wage $(88.9 \%$ in the control group and $100 \%$ in the treatment group). So, it can be said that the ability of parents to provide vegetables and fruit is relatively homogeneous. The nutritional status of the subjects varied with $50 \%$ of the control group and $77.8 \%$ of the treatment group having normal nutritional status.

At the beginning of the study, the knowledge scores, fiber consumption, types of vegetables \& fruit, also consumption of fruits showed almost the same numbers between the two groups. It can be concluded that the condition of the subject before the intervention has the same characteristics. Prior to the intervention, some respondents $(50 \%)$ in the treatment group still had low nutrition knowledge. Likewise, with the consumption of vegetables and fruit, $94.4 \%$ of the control group and $100 \%$ of the treatment group showed a severe deficit in the fiber intake. The types and amounts of fruit vegetables

Table 4. Difference of nutrition knowledge and consumption of fruit \& vegetables before and after the intervention in the treatment group

\begin{tabular}{|c|c|c|c|}
\hline \multirow[b]{2}{*}{ Variable } & \multicolumn{2}{|c|}{ Mean \pm SD } & \multirow[b]{2}{*}{$\mathbf{P}$} \\
\hline & $\begin{array}{c}\text { Before } \\
\text { intervention }\end{array}$ & $\begin{array}{c}\text { After } \\
\text { intervention }\end{array}$ & \\
\hline $\begin{array}{l}\text { Score of nutrition } \\
\text { knowledge }\end{array}$ & $8.72 \pm 1.9$ & $12.94 \pm 2.6$ & $<0.001 \mathrm{a}^{*}$ \\
\hline Fiber intake (g) & $5.69 \pm 2.7$ & $5.92 \pm 3.1$ & $0.758^{b}$ \\
\hline $\begin{array}{l}\text { Type of } \\
\text { vegetables/ week }\end{array}$ & $2.94 \pm 1.6$ & $3.61 \pm 3.1$ & $0.385^{\mathrm{a}}$ \\
\hline $\begin{array}{l}\text { Types of fiber/ } \\
\text { week }\end{array}$ & $2.33 \pm 1.6$ & $2.22 \pm 1.8$ & $0.801^{\mathrm{b}}$ \\
\hline $\begin{array}{l}\text { Vegetable intake } \\
\text { (g) }\end{array}$ & $53.18 \pm 40.5$ & $51.79 \pm 43.2$ & $0.679^{a}$ \\
\hline Fruit intake (g) & $71.40 \pm 71.1$ & $81.04 \pm 56.2$ & $0.510^{\mathrm{a}}$ \\
\hline
\end{tabular}

${ }^{a}$ Wilcoxon test ${ }^{b}$ Paired T-Test; $*$ Significant $(\mathrm{p}<0,05)$ 
Table 5. Changes in the subject's nutrition knowledge and fruit vegetable consumption after the intervention

\begin{tabular}{lccc}
\hline \multirow{1}{*}{ Variable } & \multicolumn{2}{c}{ Mean \pm SD } & p \\
\cline { 2 - 3 } & Control & Treatment & \\
\hline $\begin{array}{l}\Delta \text { Nutrition } \\
\text { knowledge } \\
\text { (score) }\end{array}$ & $0.83 \pm 2.2$ & $4.22 \pm 2.5$ & $<\mathbf{0 . 0 0 1}^{\mathbf{a}^{*}}$ \\
$\begin{array}{l}\Delta \text { Fiber intake } \\
(\mathrm{g})\end{array}$ & $0.13 \pm 2.4$ & $0.23 \pm 3.1$ & $0.914^{\mathbf{a}}$ \\
$\begin{array}{l}\Delta \text { Type of veg- } \\
\text { etables/ week }\end{array}$ & $-0.11 \pm 1.7$ & $0.67 \pm 2.3$ & $0.448^{\mathbf{b}}$ \\
$\begin{array}{l}\Delta \text { Type of fiber/ } \\
\text { week }\end{array}$ & $-0.28 \pm 1.3$ & $-0.11 \pm 1.8$ & $0.921^{\mathbf{b}}$ \\
$\begin{array}{l}\Delta \text { Vegetable } \\
\text { intake (g) }\end{array}$ & $4.54 \pm 32.9$ & $-1.39 \pm 37.3$ & $0.616^{\mathbf{a}}$ \\
$\begin{array}{l}\Delta \text { Fruit intake (g) } \\
\text { a }\end{array}$ & $25.46 \pm$ & $0.67 \pm 2.3$ & $0.362^{\mathbf{a}}$ \\
\hline
\end{tabular}

${ }^{\mathrm{a}}$ Independent $\mathrm{T}$ Test ${ }^{\mathrm{b}}$ Mann Whitney Test; *Significant $(\mathrm{p}<0,05)$

consumed also do not meet the specified adequacy standards. However, according to the subject's initial data before the intervention, the consumption of vegetables and fruit in the treatment group was better than the control group.

The recommendation for vegetables and fruit consumption according to the World Health Organization (WHO) in a day is at least 400 grams with details of 250 grams of vegetables (equivalent to 2 servings) and 150 grams of fruit (equivalent to 3 medium sized Ambon bananas or 1 medium piece of papaya). The recommendation to eat vegetables and fruit for Indonesians, especially toddlers and school children, is $300-400$ grams, followed by a variety of food choices (Indah, 2018).

In Table 2, it is known that before the intervention, most of the subjects consumed vegetables and fruits less than 250 grams and 150 grams. Apart from that, the types consumed within one week are also only a few. In the control group only 1 person (5.6\%) consumed $\geq 7$ types of vegetables per week. While all subjects $(100 \%)$ in the treatment group consumed $<7$ types of vegetables per week. Likewise, fruit consumption, all subjects consumed $<7$ types of fruit within a week. It can be said that most of the subjects did not consume a variety of vegetables and fruits.

Based on table 3 and table 4, the results of the nutrition knowledge score before intervention in the control group was $9.44 \pm 1.7$ and after the intervention was $10.28 \pm 1.4$. Despite the improvement, statistical tests using the Wilcoxon test showed no significant difference ( $p>0.05)$ between knowledge before and after the intervention in the control group. This is because the control group was not given nutrition education. Whereas in the treatment group, the results before the intervention was $8.72 \pm 1.9$ and after the intervention was increased to 12.94 \pm 2.6. Statistical tests using the Wilcoxon test showed that there was a significant difference (p $<0.05$ ) between the knowledge before and after the intervention in the treatment group. In addition, there was a significant difference in the mean change in knowledge between the control group and the treatment group $(\mathrm{p}<0.05)$, where the mean of the treatment group was $4.22 \pm 2.49$. This is in line with Ronasari's research which states that there is an effect of nutrition education on the knowledge of the importance of vegetables in preschool children (Putri \& Maemunah, 2017).

Based on the knowledge score before the intervention, it was found that the lowest knowledge score was in the section on matching the benefits of vegetables and fruit. The knowledge score after the intervention in the control group did not change, while the treatment group had an increase. Most of the subjects were able to distinguish between vegetables and fruit, although it was still difficult to distinguish between each type of vegetable or fruit. Some subjects have difficulty in matching the text and pictures. This is because children aged 5-6 years are still in kindergarten $\mathrm{A}$ or small kindergarten, so they have not been taught to read and write.

Knowledge is defined as factual and interpretive information that leads to an understanding that is useful for making informed decisions or actions (Glanz, et al., 2002). Knowledge can increase if someone is given education. Interventions by providing education can increase a person's knowledge and behavior (Mahmood, et al., 2014). Knowledge can also be obtained from the learning process. Increased knowledge is influenced by several factors, one of which is the existence of learning methods or educational media. In the treatment group, the subjects were given education using the sociodrama learning method. This game combines 2 elements, namely imitative and imaginative. Imitative, which 
is when children imitate someone's actions or words. Meanwhile, imaginative children use their imagination to create what they imitate (Smilansky, 1968). The elements in sociodrama games are also characteristic of children aged 5-6 years where the children are more receptive to the information provided. In addition, education through the senses of hearing and sight gives $35-55 \%$ higher results than just hearing, which is only $15 \%$ (Syah, 2017).

Sibagariang, et al. (2016) study showed that nutrition education using extension methods and guessing games is more effective than nutrition education through extension methods alone. Dyah's research (2016) concluded that there was a positive effect of the sociodrama learning method on the creativity of children's drawing work in group B students of Asih Sejati Kindergarten, Yogyakarta. In addition, the application of the sociodrama method in the subject of providing excellent service to class XI students of SMK in Semarang can also improve students' skills in providing assistance to customers.

Although research using the sociodrama learning method for children is still rare, the results of several studies show that there is a positive effect of the sociodrama method on increasing knowledge and changing the behavior of the subjects (Rosy, 2017). By the age of 3 , children begin to develop a strong interest in roles and social relationships. That is why children begin to imitate and explore roles that are usually done by adults (Karpov, 2015). Rahardjo's research (2016) explains that sociodrama games have a positive influence on children's cognitive development such as problem solving, language development, skills, reading and writing skills, arithmetic, imagination and other developments. When playing sociodrama games, it is necessary to have adults explain different social roles to children so as to encourage behavioral development. Knowledge has a significant relationship with changes in a person's behavior, including one's own attitude. Knowledge is very important in shaping individual actions. Increased knowledge and understanding of behavior will increase the intention to implement such behaviors (Gusti, 2016; Mnguni, et al., 2015).

The results of fiber intake measurements in the treatment group before the intervention was 5.69 \pm 2.7 and after the intervention was $5.92 \pm 3.1$. Although there was a slight increase, there was no significant difference found ( $\mathrm{p}>0.05$ ). According to the Nutritional Adequacy Rate in Indonesia (AKG), children aged 4-6 years need 22 grams of fiber a day. Fiber itself is found in many vegetables and fruits. According to in-depth interviews conducted with the subject's parents, parents tend to provide fast food or junk food such as sausages, nuggets and others to children. Apart from being easier to serve, children also prefer these foods. Fast food is food that is high in calories and low in micronutrients such as vitamins, minerals, amino acids and fiber, so it is sufficient to contribute to the adequacy of the subject's fiber (Ashakiran \& Deepthi, 2012).

Types of vegetables and number of fruit consumed also increased but not significant in the treatment group. Changing behavior from not liking to being willing to consume even liking vegetables and fruit requires a long educational process. Research on nutrition education using picture books conducted on children aged 2-4 years showed a change in fruit vegetable consumption after 4 weeks of education, but the results were not significant (Bestari \& Pramono, 2014). The nutrition education that is given once is less able to maintain nutritional knowledge for one month so that it will affect behavior change (Irnani \& Sinaga, 2018).

Based on the theory of behavior change, a person experiences new behavior changes through 3 stages, including the stage of changing knowledge (knowledge), followed by attitudes (affective) and finally practice (practice). At the knowledge stage, an individual will adopt a behavior if he knows the meaning and benefits of the behavior. After knowing the benefits of this behavior, someone will judge or act on the stimulus. At the practical stage, someone will practice or implement what they know and act on (Agustini, 2014). H.L. Blum in behavior theory says that there is a change in behavior due to changes in knowledge and attitudes, but the change process takes a long time with the interaction of various components of behavior (Bestari \& Pramono, 2014). Meanwhile, the intervention conducted by researchers was only carried out for one week. 
Even though there is a significant change in knowledge, this does not necessarily change the child's eating behavior. There are internal factors in children such as preferences for eating. Early in life, most babies and children prefer sweet and salty tastes. Sweet taste is a strong psychobiological stimulus for animal species including humans. Meanwhile, bitter tastes such as vegetables are often rejected when first exposed and can change when given repeated exposure. The innate tendency to refuse sour and bitter foods initially protects the individual from toxins, but it also causes a child to have a dislike for vegetables. Taste perception can vary between individuals depending on the variation of taste receptor genes (De Cosmi et al., 2018; Scaglioni, et al., 2011).

Judged from the measurement results after the intervention, although there was no significant difference, total types of vegetables and fruit had increased while the intake did not increase. This shows that the change in behavior experienced by children has reached the stage of increasing variation but not the amount. Apart from internal factors, there are several external factors that influence children's eating behavior. In children, the stages of receiving information to changing behavior cannot be done alone, but there are roles from parents, family environment, school, and also the media. The way for children to have preferences for food is by introducing these foods to children. When the family environment or parents do not provide and consume a variety of foods, then the opportunity for children to be exposed is smaller (Ansem, et al., 2015). This of course will affect the behavior and eating habits of children.

Apart from the factors of parents, teachers and the school environment also play a role in introducing variations in vegetables and fruits to children. If children are not accustomed to knowing the kinds of vegetables and fruits at school and the amounts that must be consumed, the children will also not get used to it. According to in-depth interviews, it was found that the habit of eating vegetables and fruit together at school is done once a month. Every day, the subject is recommended to bring snack to school. Snacks are usually high in calories and low in fiber.
Media exposure also has a major influence on children's eating behavior. Other studies have shown a significant relationship between media exposure and vegetable \& fruit consumption behavior (Rachman, et al., 2017). One of the roles of the media that can influence the behavior of eating vegetables and fruit is advertising in electronic media. Unfortunately, there are very few advertisements regarding vegetables and fruit and the packaging is not attractive so that the message conveyed does not reach the children.

\section{CONCLUSION}

Nutrition education using the sociodrama method is effective in increasing nutritional knowledge, but it did not change vegetable and fruit intake in children aged 5-6 years. Further research is needed regarding the provision of nutrition education using the sociodrama method as a method of introducing vegetables and fruits to children with a more longer duration, more frequent, and involving the roles of parents at home and teachers at school.

\section{ACKNOWLEDGEMENT}

This research was funded by a community service grant from the Faculty of Medicine, Diponegoro University.

\section{REFERENCES}

Agustini, A. (2014). Promosi Kesehatan (D. W. Handayani, Ed.). Sleman: Deepublish.

Ansem, W.J.C.V, Schrijvers, C.T.M., Rodenburg, G., \& Mheen, D.V.D. (2015). Children's snack consumption : role of parents, peers and child snack-purchasing behaviour. Results from the INPACT study. European Journal of Public Health, 25(6), 1006-1011.

Ashakiran, \& Deepthi, R. (2012). Fast Foods and their Impact on Health. Journal of Krishna Institute of Medical Sciences University, 1(2), 7-15.

Barbosa, L.B., Vasconcelos, S.M.L., Correia, L.O.S., \& Ferreira, R.C. (2016). Estudos de avaliação do conhecimento nutricional de adultos: uma revisão sistemática. Ciência \& Saúde Coletiva, 21(2), 449-462. 
Bestari, G.S., \& Pramono, A. (2014). Pengaruh edukasi gizi menggunakan media buku cerita bergambar terhadap perubahan konsumsi buah dan sayur anak di PAUD Cemara Semarang. Journal of Nutrition College, 3(4), 918-924.

De Cosmi, V., Parazzini, F., Brambilla, P., Agostoni, C., Ciappolino, V., \& Scaglioni, S. (2018). Factors Influencing Children's Eating Behaviours. Nutrients, 10(6), 706.

Desi, Mesyamtia, B., \& Ginting, M. (2018). Pendidikan gizi melalui permainan wayang terhadap peningkatan konsumsi sayur dan buah. Jurnal Vokasi Kesehatan, 4(1), 23-27.

Dyah R.S. (2016). Pengaruh Metode Pembelajaran Sosiodrama Terhadap Kreativitas Berkarya Menggambar Anak Pada Kelompok B Taman Kanak-Kanak Asih Sejati Yogyakarta. Jurnal Pendidikan Seni Rupa Edisi Vol 5, No 1 .

Gisi B., \& Pramono, A. (2014). Pengaruh Edukasi Gizi Menggunakan Media Buku Cerita Bergambar terhadap Perubahan Konsumsi Buah dan Sayur Anak di PAUD Cemara Semarang. Journal of Nutrition College, 3(4), 918-924.

Glanz, K., Rimer, B., \& Lewis, F. (2002). Health Behavior and Health Education: Theory, Research and Practice (3rd ed.). San Fransisco: Jossey-Bass Publications.

Graziose, M.M., \& Ang, I.Y.H. (2018). Factors related to fruit and vegetable consumption at lunch among elementary students: a scoping review. Preventing Chronic Disease, 15(E55), $1-12$.

Gusti, A. (2016). The relationship of knowledge, attitudes, and behavioral intentions of sustainable waste management on primary school students in City of Padang, Indonesia. International Journal of Applied Environmental Sciences, 11(5), 1323-1332.

Hermina, H., \& Prihatini. (2016). Gambaran konsumsi sayur dan buah penduduk indonesia dalam konteks gizi seimbang: analisis lanjut survei konsumsi makanan individu (SKMI) 2014. Buletin Penelitian Kesehatan, 44(3), 4-10.

Indah, I.S. (2018). Infodatin : Pusat data dan informasi Kementerian Kesehatan RI.

Irnani, H., \& Sinaga, T. (2018). Pengaruh pendidikan gizi terhadap pengetahuan, praktik gizi seimbang dan status gizi pada anak sekolah dasar. Jurnal Gizi Indonesia, 6(1), 58.

Karpov, Y.V. (2015). Neo-vygotskian developmental theory. In International Encyclopedia of Social
\& Behavioral Sciences (Second Edi, Vol. 16, pp. 511-517).

Kemendikbud RI. (2014). Peraturan Menteri Pendidikan dan Kebudayaan Republik Indonesia Nomor 137 Tahun 2014 Tentang Standar Nasional Pendidikan Anak Usia Dini. Indonesia.

Kemendikbud RI. (2015). Petunjuk teknis penyelenggaraan taman kanak-kanak.

Kementerian Kesehatan RI. (2011). Keputusan Menteri Kesehatan Republik Indonesia tentang Standar Antropometri Penilaian Status Gizi Anak (p. 4). p. 4.

Khairunnisya, R., Sudaryati, E., \& Nasution, E. (2017). Effect of role play method on food choice behavior in state basic students 060933 District Medan Johor City Medan Year 2016. Journal Of Humanities And Social Science, 22(6), 49-54.

Lucas, B.L., \& Feucht, S.A. (2008). Nutrition in childhood. In L. K. Mahan \& S. Escott-Stump (Eds.), Krause's Food \& Nutrition Therapy (12th ed., pp. 222-223). St. Louis, Missouri.

Mahmood, N., Othman, S., Al-Tawil, N., \& AlHadithi, T. (2018). Impact of an education intervention on knowledge of high school students concerning substance use in Kurdistan Region-Iraq: A quasi-experimental study. PLoS ONE, 13(10), 1-9.

Martins, V.J.B., Toledo Florêncio, T.M.M.V., Grillo, L.P., Do Carmo, P., Franco, M., Clemente, A.P.G., Martins, P.A., ... Sawaya, A.L. (2011). Longlasting effects of undernutrition. International Journal of Environmental Research and Public Health, 8(6), 1817-1846. doi: 10.3390/ ijerph 8061817

Mclennan, D.P. (2008). Kinder - caring : exploring the use and effects of sociodrama in a kindergarten classroom. 2(1), 74-88.

Mnguni, L., Abrie, M., \& Ebersohn, L. (2015). The Relationship between scientific knowledge and behaviour: An HIV/AIDS Case. Journal of Biological Education, 50(2), 147-159.

Muckenhuber, J., Großschädl, F., Burkert, N.T., Freidl, W., \& Rásky, É. (2014). Nutrition and health - the association between eating behavior and various health parameters: a matched sample study. PLoS ONE, 9(2), e88278.

Nekitsing, C., Hetherington, M.M., \& Blundellbirtill, P. (2018). Developing healthy food preferences in preschool children through taste exposure, sensory learning, and nutrition 
education. Current Obesity Reports, 7(60), 60-67.

Putri, R.M., \& Maemunah, N. (2017). Peran pendidikan kesehatan dalam meningkatkan pengetahuan anak tentang pentingnya sayur. Jurnal Keperawatan, 8(1), 54-64.

Rachman, B.N., Mustika, I.G., \& Kusumawati, I. G.A.W. (2017). Faktor yang berhubungan dengan perilaku konsumsi buah dan sayur siswa SMP di Denpasar. Jurnal Gizi Indonesia, 6(1), 9-16.

Rahardjo, M.M. (2016). Indonesian journal of early childhood bringing vygotskian approach into early childhood education in Indonesia : Empowering the daycare. Indonesian Journal of Early Childhood Education Studies, 5(1).

Rosy, B. (2017). Sociodrama method; stimulate the development of attitudes, knowledge and skills of students in excellent service learning. Jurnal Pendidikan Bisnis Dan Manajemen, 3(1), 25-34.

Scaglioni, S., Arrizza, C., Vecchi, F., \& Tedeschi, S. (2011). Determinants of children's eating behavior. American Journal of Clinical Nutrition, 94, 2006-2011.

Sibagariang, I.T.A., Siagian, A., \& Ardiani, F. (2016). Pengaruh penyuluhan tentang sayur dan buah dengan metode ceramah dan bermain tebak rasa terhadap pengetahuan dan sikap dalam konsumsi sayur dan buah pada siswa SDN
067254 Kecamatan Medan Deli tahun 2016. Jurnal Kesehatan Masyarakat, 99-102.

Smilansky, S. (1968). The effects of sociodramatic play on disadvantaged preschool children. United states: John Wiley \& Sons, Inc.

Sossauer, G., Zbinden, M., Tebeu, P.M., Fosso, G.K., Untiet, S., Vassilakos, P., \& Petignat, P. (2014). Impact of an educational intervention on women's knowledge and acceptability of human papillomavirus self-sampling: a randomized controlled trial in cameroon. PLoS ONE, 9(10), $1-8$.

Syah, M. (2017). Psikologi pendidikan dengan pendekatan baru. Bandung: Remaja Rosdakarya.

Wawan, A. (2011). Teori dan pengukuran pengetahuan sikap dan perilaku manusia: dilengkapi contoh kuesioner. Yogyakarta: Nuha Media.

Wong, D.L., Hockenberry-Eaton, M., Wilson, D., Winkelstein, M.L., \& Schwart, P. (2008). Peningkatan kesehatan anak prasekolah dan keluarga. In Buku Ajar Keperawatan Pediatrik (1st ed., pp. 493-495).

Wong, D.L., Hockenberry-Eaton, M., Wilson, D., Winkelstein, M. L., \& Schwart, P. (n.d.-b). Peningkatan kesehatan todler dan keluarga. In Buku Ajar Keperawatan Pediatrik (1st ed. 464-467). 